\title{
Development of decree 1072 of 2015, as a regulatory factor of practices in the construction field for the prevention of workplace accidents with MHF Construark SAS, carried out during the year 2020 in Bogotá
}

Desarrollo del Decreto 1072 de 2015, como factor regulador de prácticas en el ámbito de la construcción para la prevención de accidentes laborales con MHF Construark SAS, realizado durante el año 2020 en Bogotá

Desenvolvimento do Decreto 1.072 de 2015, como fator regulador das práticas na área da construção para a prevenção de acidentes de trabalho com MHF Construark SAS, realizado durante 2020 em Bogotá

\section{Daniel Augusto Tabares Barrera ${ }^{1}$ Ever Angel Fuentes Rojas ${ }^{2}$}

Received: November $24^{\text {th }}, 2020$

Accepted: February $20^{\text {th }}, 2021$

Available: May $5^{\text {th }}, 2021$

How to cite this article:

A. Tabares Barrera, E. A. Fuentes Rojas, "Development of Decree 1072 of 2015, as a Regulatory Factor of Practices in The Construction Field for The Prevention Of Workplace Accidents With Mhf Construark SAS, Carried Out During The Year 2020 In Bogota," Revista Ingeniería Solidaria, vol. 17, no. 2, 2021. doi: https://doi.org/10.16925/2357-6014.2021.02.11

Reflection article. https://doi.org/10.16925/2357-6014.2021.02.11

Student of the Industrial Engineering Department, Faculty of Engineering, Universidad Libre, Bogotá, Colombia

Email: Daniela.tabaresb@unilibrebog.edu.co

ORCID: https://orcid.org/0000-0002-1013-6433

CVLAC: https://scienti.minciencias.gov.co/cvlac/visualizador/generarCurriculoCv.do?cod_rh=0001 823547

Universidad Libre, Seccional Bogotá, Sede Bosque Popular, Carrera 70 \#53 - 40

2 Full-Time Professor of the Industrial Engineering Department, Faculty of Engineering, Universidad Libre, Bogotá, Colombia

Email: ever.fuentes@unilibre.edu.co

ORCID: https://orcid.org/0000-0001-7504-5164

CVLAC: https://scienti.minciencias.gov.co/cvlac/visualizador/generarCurriculoCv.do?cod_rh=0000 969982 
2 Development of decree 1072 of 2015, as a regulatory factor of practices in the construction field for the prevention of workplace accidents with MHF Construark SAS, carried out during the year 2020 in Bogotá

\section{Abstract}

Introduction: This article "Development of Decree 1072 of 2015, as a regulatory factor of practices in the construction field for the prevention of workplace accidents with MHF Construark SAS" was executed during 2020 in Bogotá.

Background: There has been recurring practices in the construction sector that generate difficulties in the implementation of the SGSST, which may be the main cause of this insufficient implementation, which can lead to workplace accidents and occupational diseases.

Objective: The objective of the investigation is to establish the level of compliance in the implementation of the SGSST, in order to identify determining factors that negatively affect such a process.

Methods: This research resulted in the design of a study with a predominantly qualitative approach. Interviews were conducted with company representatives from the administrative area in charge of implementing the SGSST.

Results: The MHF Company has achieved an implementation level of 85\%; a high level.

Conclusion: This project contributes to the research in terms of the study of SGSST in particular, from a perspective that queries factors related to the role of key factors such as senior management and construction personnel.

Originality: A small business of the construction field is investigated, setting up human factors in the SGSST implementation processes and the improvement strategy.

Limitations: Information gathering on-site was affected due to the circumstances generated by COVID-19 due to the fact that the construction field was forced to suspend work as consequence of the pandemic.

Keywords: Safety and health at work system (SG-SST), Fulfillment, Management systems, Decree 1072.

\section{Resumen}

Introducción: Este artículo "Desarrollo del Decreto 1072 de 2015, como factor regulador de prácticas en el campo de la construcción para la prevención de accidentes laborales con MHF Construark SAS" fue ejecutado durante 2020 en Bogotá.

Antecedentes: Ha habido prácticas recurrentes en el sector de la construcción que generan dificultades en la implementación del SGSST, que puede ser la principal causa de esta insuficiente implementación, que puede derivar en accidentes laborales y enfermedades ocupacionales.

Objetivo: El objetivo de la investigación es establecer el nivel de cumplimiento en la implementación del SGSST, con el fin de identificar los determinantes que inciden negativamente en dicho proceso.

Métodos: Esta investigación resultó en el diseño de un estudio con un enfoque predominantemente cualitativo. Se realizaron entrevistas con representantes de empresas del área administrativa encargada de implementar el SGSST.

Resultados: La empresa MHF ha alcanzado un nivel de implementación del 85\%; un alto nivel.

Conclusión: Este proyecto contribuye a la investigación en términos del estudio de SGSST en particular, desde una perspectiva que cuestiona factores relacionados con el rol de factores clave como la alta dirección y el personal de construcción.

Originalidad: Se investiga una pequeña empresa del campo de la construcción, estableciendo factores humanos en los procesos de implementación del SGSST y la estrategia de mejora. 
Limitaciones: La recopilación de información en sitio se vio afectada por las circunstancias generadas por COVID-19 debido a que el campo de construcción se vio obligado a suspender las obras como consecuencia de la pandemia.

Palabras clave: Sistema de seguridad y salud en el trabajo (SG-SST), Cumplimiento, Sistemas de gestión, Decreto 1072.

\section{Resumo}

Introdução: Este artigo "Elaboração do Decreto 1.072 de 2015, como fator regulador das práticas na área da construção para a prevenção de acidentes de trabalho com MHF Construark SAS" foi executado durante o ano de 2020 em Bogotá.

Antecedentes: Existem práticas recorrentes no setor da construção que geram dificuldades na implementação do SGSST, podendo ser a principal causa desta implementação insuficiente, podendo originar acidentes de trabalho e doenças ocupacionais.

Objectivo: O objectivo da investigação é estabelecer o grau de cumprimento na implementação do SGSST, de forma a identificar os determinantes que afectam negativamente o referido processo.

Métodos: Esta pesquisa resultou no desenho de um estudo com abordagem predominantemente qualitativa. Foram realizadas entrevistas com representantes de empresas da área administrativa responsáveis pela implantação do SGSST.

Resultados: A empresa MHF atingiu um nível de implantação de 85\%; um alto padrão.

Conclusão: Este projeto contribui para a pesquisa em termos do estudo SGSST em particular, a partir de uma perspectiva que questiona fatores relacionados ao papel de fatores-chave como a alta administração e o pessoal da construção.

Originalidade: Investiga-se uma pequena empresa do ramo da construção, estabelecendo fatores humanos nos processos de implantação do SGSST e na estratégia de melhoria.

Limitações: A coleta de informações no local foi afetada pelas circunstâncias geradas pelo COVID-19, já que o campo de construção foi forçado a suspender as obras como resultado da pandemia.

Palavras-chave: Sistema de segurança e saúde ocupacional (SG-SST), Compliance, Sistemas de gestão, Decreto 1.072

\section{INTRODUCTION}

This work is the product of the research process carried out at MHF Construark SAS, a construction company where the implementation of the SGSST was evaluated and an improvement proposal was presented. The enquiry about the different systems regulated in the country to be applied in companies in order to improve quality levels from the perspective of processes and procedures, emerged as the central interest to develop this work. Particularly in the workplace, Health and safety consists of the development of a logical and phased process, based on continuous improvement and that includes policy, organization, planning, application, evaluation and audit. To anticipate, recognize, assess and control risks that may affect safety and health at work. 
4 Development of decree 1072 of 2015, as a regulatory factor of practices in the construction field for the prevention of workplace accidents with MHF Construark SAS, carried out during the year 2020 in Bogotá

In specific terms, this work focuses on determining and characterizing the SGSST, within MHF Construark SAS; a company which falls within the category of civil works and construction of non-residential buildings. The work assesses the level of risk that companies related to this field are intended to determine, as well as establishing the significant factors that make the implementation of the SGSST, which means the latency of risks in the development of functions of the organization in question. Based on the above, a strategy is designed with the purpose of improving the actions to improve the implementation of the SGSST. Due to the fact that in an organization in the construction sector, there is a high recurrence of work accidents that on many occasions generate loss of human lives [39].

The design and execution of the health and safety system has proven to decrease the recurrence of workplace accidents in the construction field. This system was implemented, starting in 2012, through Law 1562 and Decree 1072 of 2015, allowing for a gradual improvement of health and safety conditions at work, decreasing the occurrence of workplace accidents at the same time in the construction field.

However, there has been a process of resistance to change throughout the implementation, mainly on behalf of the central actors of the system, that is, workers in the construction field [38].

Thereby, the relevance of this work consists in contributing to the settlement of the reasons or motives that cause the difficulty of carrying out an adequate process of implementation of this system in a particular company in the sector. Specifically, this work will contribute to the knowledge of such factors (causes), contributing to the company's improvement strategies in order to strengthen the system implementation processes. In addition, it seeks to understand the motivations and factors that make a person resist implementing these measures, knowing that they are for their own benefit and also for the organization.

This sort of research provides a great contribution to the social field, while also determines the difficulties and proposing strategies to improve the implementation of the SGSST which is committed to reducing workplace accidents that sometimes even cause loss of human life and this, of course, has a significant impact that can affect the family structure of the victims. Consequently, the impact on the economic field is also tremendous, in which, the fewer workplace accidents, the lower the economic expenditure of companies and insurance companies. In the professional field, it not only provides specific knowledge for the academic disciplines that address this sort of problem, but also improves professional practices in specific areas such as construction sites. Therefore, it is brand new to enquire about the factors, if you will, the cultural (workers' own values) and even psychological factors that motivate workers to ignore the recommendations included on the system. 
Although this research is focused on a local case, specifically, it takes place in Bogotá. This does not mean that the work carried out does not contribute to the change of the research in the national and even international context. For instance, the research developed to establish the level of implementation of the SGSST in Cuba [1], or the research carried out in 1997 in Argentina, where the analysis of the relationship between work and workplace diseases was carried out, within the framework of government reforms looking forward to mitigate the effects that diseases can have on workers and companies [2], as well as the impact generated by workplace accidents in Portugal in the fishing field, due to its high incidence in other fields [3]. These topics are closely related to the proposed topic as they focus on the importance of health and safety management systems at work, but also on the impacts of general workplace accidents in social terms.

\section{RESEARCH BACKGROUND}

The construction field in Colombia has been described as a significant driving force of the national economy. However, this sector has been negatively affected in macroeconomic growth figures, not only because the business has slightly slowed down, but also due to the pandemic, which has had a tremendous impact.

Civil works Buildings Related activities Building

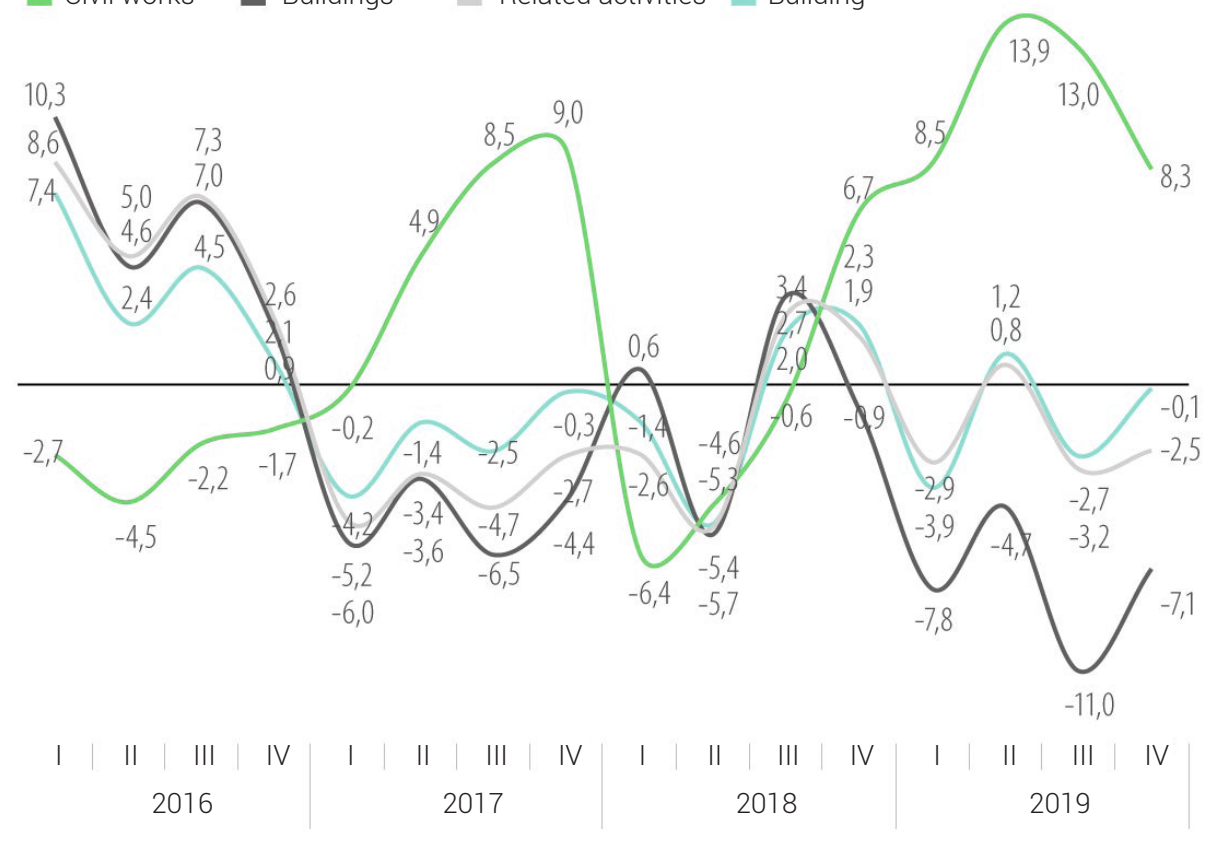

Graph 1. Construction Field Growth GDP

Source: Newspaper the Republic 2020 [4] 
Graph 1 shows a detailed behavior of the sector in the last 4 years, under normal operation. A significant rebound in sectors such as buildings and constructions can be seen, but they fail to achieve positive behavior. Civil works growth has been decreasing significantly but its figures are still positive (at 8.3). MHF Construark SAS is located in this last component of the construction sector, which helps give rise to economic stability, and despite the gradual decrease in this, positive figures are still present (before the pandemic).

Another important component within the construction sector is the type of human resource that make up a company in this sector. In the case of MHF Construark SAS, its composition is given by its organic structure, as shown in Graph 2.

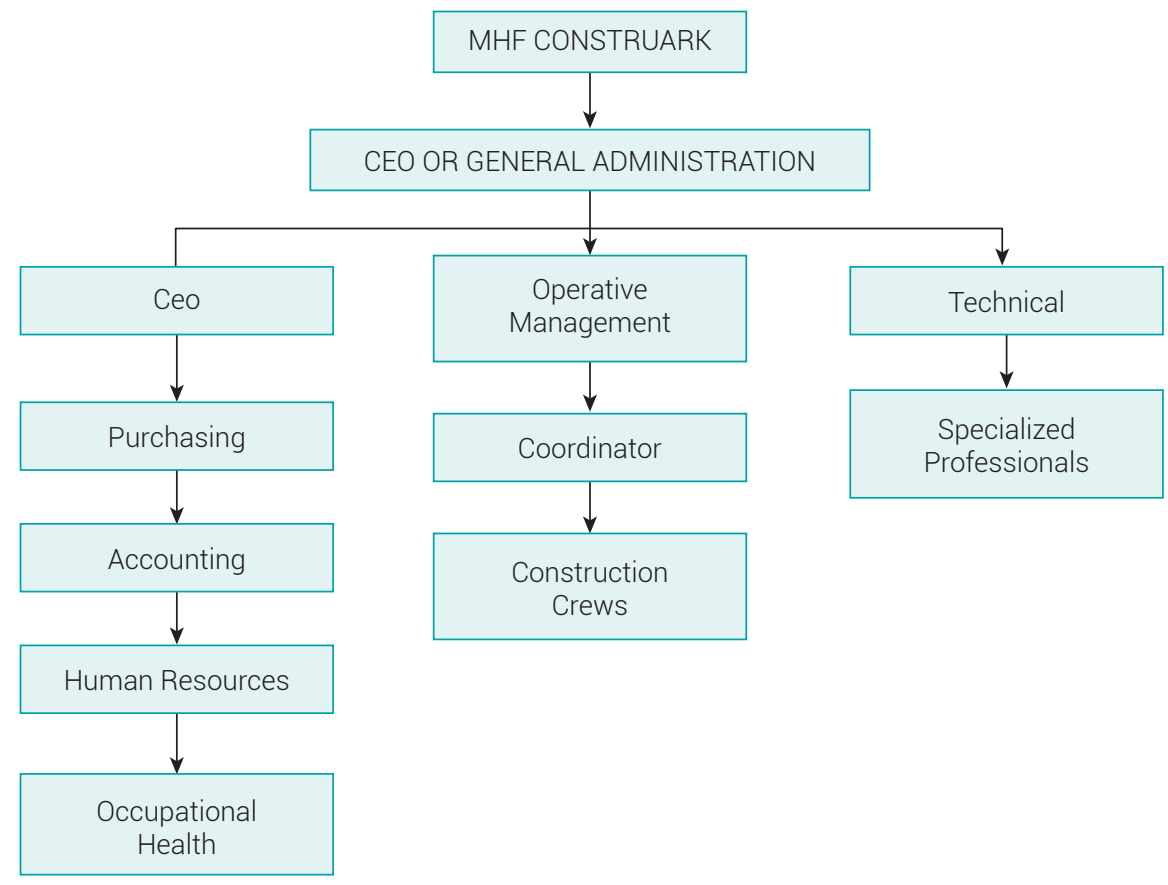

\section{Graph 2. Organization chart \\ Source: Own work}

Crucial points were set up in the implementation in relation to some determining factors within the company throughout the development of the research work. the role of senior management and the people who belong to the operational area must be considered, where they interact with various specific roles such as the workforce, which "is currently composed of: Construction manager, Construction Expeditor, engineer, contract manager, construction foreman, construction workers and so on and so forth." [5] Table 1 summarizes these roles and their respective tasks. 
Table 1. Roles and tasks in a construction contract

\begin{tabular}{|c|c|}
\hline Position & Functions \\
\hline Construction Manager & $\begin{array}{l}\text { Manages the development of the work in aesthetic, environmental, legal and urban } \\
\text { aspects. They are responsible for planning, budgeting, and overseeing progress. }\end{array}$ \\
\hline Contact Manager & $\begin{array}{l}\text { Executes the ideas of the project, while controlling and managing the quality of the } \\
\text { construction material, technical regulations, safety and economy on the construc- } \\
\text { tion site }\end{array}$ \\
\hline Assistant & Provide direct assistance to the construction expeditor \\
\hline Construction Expeditor & $\begin{array}{l}\text { The construction expeditor manages the flow of materials from supplier to project. } \\
\text { They must be able to determine what materials and equipment will be needed in } \\
\text { any given project, order those materials, and manage timely delivery. This person } \\
\text { must be well organized and detailed to be able to keep track of the flow of material } \\
\text { on a given schedule as they are often working for many projects at once. They work } \\
\text { closely with both the suppliers and the companies, which entails constant commu- } \\
\text { nication between parties. }\end{array}$ \\
\hline Expeditor Junior & He is in charge of the execution, and depends on the construction expeditor \\
\hline \multirow{2}{*}{ Construction worker } & Plan Reading \\
\hline & Cleaning of debris, loading and unloading of material on site \\
\hline \multirow{2}{*}{ Apprentice } & Apprentice \\
\hline & [5] \\
\hline
\end{tabular}

Source. Own work

In this brief description you can see the complexity of not only of the tasks required in a work, but also the several varieties of activities and characters to carry them out. Something that must be considered within the construction field is that there is a high level of informality in the recruitment and hiring of personnel, which affects the purposes established for adequate compliance with the SGSST. Due to the aforementioned, it is a determining factor to establish the necessary actions that are required to reduce the risks that these situations may generate, so "it is important that the State and private companies conceive the importance of prevention and ensure the processes and tools that make the workforce carry out their activities safely" [6].

There have been some research studies which had revealed a high rate of informality in the construction field. According to the report 'Current profile of labor informality in Colombia' presented by the Labor Observatory of the Universidad del Rosario "Work in the Construction field is typically informal, its informality rates range between 58.72\% and 85.30\%" [7]. In other words, there are many different conditions that make informality prevail in the construction field in terms of employment for the development of construction work regarding the workforce.

Hand in hand with informality, the high accident rate in the construction field is another factor that requires guaranteeing adequate processes for the implementation of the SGSST. In 2014, a high rate of workplace accidents was reported in 
the construction field. "This field is also the one with the highest number of serious accidents; In 2013, of the total accidents reported, 3,302 (1.6\%) were serious, which means, a rate of 90 serious accidents per 100,000 workers. Of that figure, 651 accidents (19.7\%) took place in the construction sector." [8]

Significant bases for the conceptual support of Quality Management systems [9] have been provided by some of the theorists of systems theory [10]. In fact, issues related to quality control are not relatively recent. There are records that place this practice from the end of the 19th century, in the nascent industries that marked the industrial revolution. Quality control was characterized by being executed entirely by the operators, which was known as the Operator's Quality Control. During the First World War, the quality control of the foreman was handed over and, between the two wars, the quality control by inspection or what we know as modern quality control appeared" [11].

In specific terms, Table 2 presents the following summary scheme of some significant events in the formation of Quality Management systems:

Table 2. Synthesis of significant events, Quality management systems

\begin{tabular}{|c|c|c|}
\hline Year & Fact & Responsible \\
\hline 1946 & $\begin{array}{l}\text { "The American Society for Quality Control (ASQC) is founded, } \\
\text { which through publications, conferences and training courses, } \\
\text { has promoted quality control in all types of products and } \\
\text { services" [11] }\end{array}$ & ASOC \\
\hline 1950 & $\begin{array}{l}\text { "A series of lectures to Japanese engineers on statistical } \\
\text { methods and on quality responsibility are given to senior } \\
\text { management personnel" [11] }\end{array}$ & Edwards Deming \\
\hline 1954 & $\begin{array}{l}\text { A visit to Japan takes place in order to "highlight the important } \\
\text { commitment of the management area to the achievement } \\
\text { of quality, that staff are trained in quality management and } \\
\text { that quality is improved at an unprecedented rate using these } \\
\text { concepts" [11] }\end{array}$ & Joseph M. Juran \\
\hline 1960 & $\begin{array}{l}\text { "The zero defects concept was created in Martin-Marietta } \\
\text { during the } 1960 \text { s, promoting the theory of doing things right } \\
\text { from the start" [11] }\end{array}$ & Philip B. Crosby \\
\hline 1962 & $\begin{array}{l}\text { "Quality control circles are created in Japan in order to achieve } \\
\text { quality improvement" [11] }\end{array}$ & Kaoru Ishikawa \\
\hline 1962 & $\begin{array}{l}\text { "The first quality control conference for supervisors is organi- } \\
\text { zed, focused on all those supervisors at the operational level" } \\
\text { [11] }\end{array}$ & $\begin{array}{l}\text { JUSE (Unión of Japanese Scien- } \\
\text { tists and Engineers) }\end{array}$ \\
\hline
\end{tabular}

Source. Own intellectual property based on information taken from Gutierrez 2005

In Colombia, regulations have been defining the path in which the management systems have been implemented in the country: 


\subsection{Regulatory Background:}

The SGSST has its origin due to the following normative antecedents, see Graph 3.

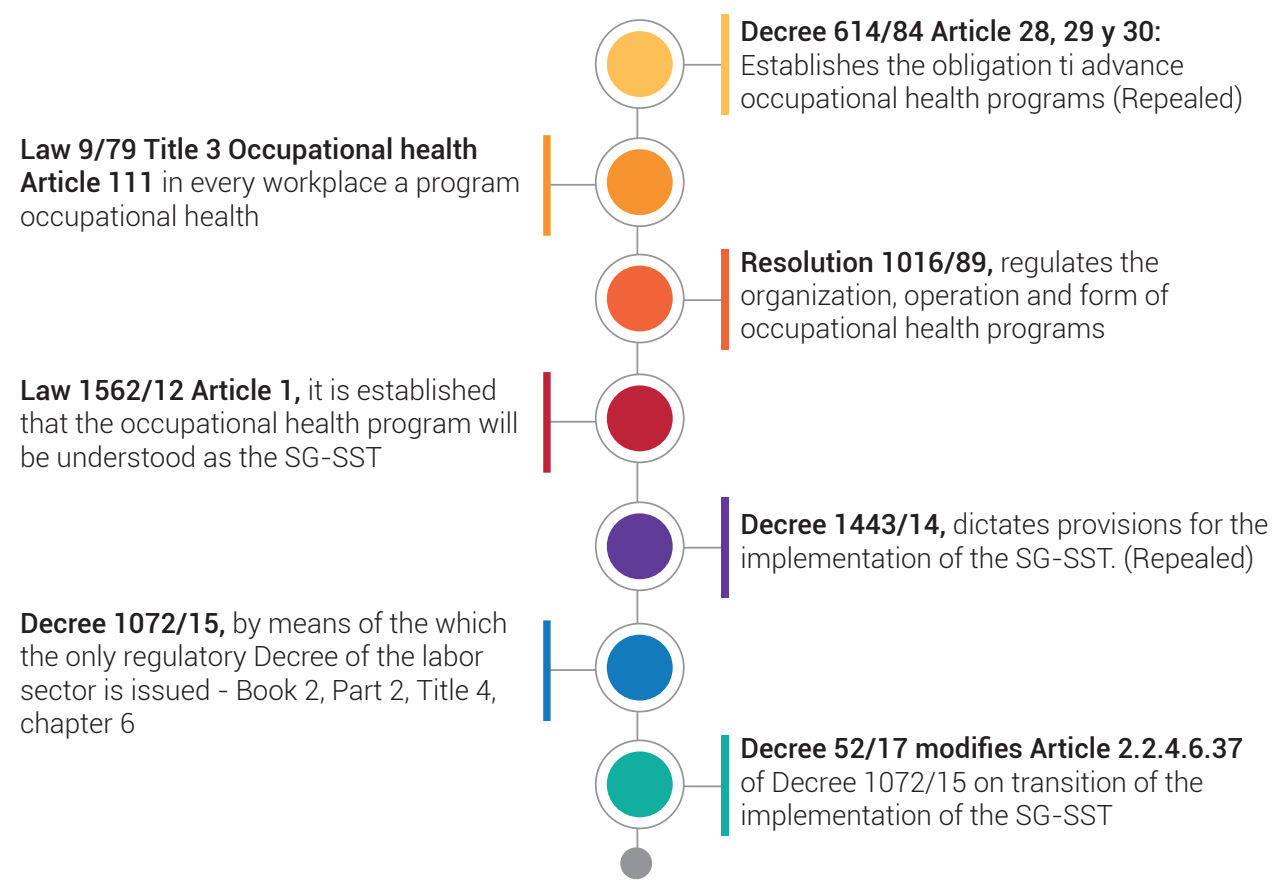

\section{Graph 3. Normative Antecedents}

Source: Ministry of work 2020 [12]

It is remarked that the issue related to workplace safety and health at work is old. Since 1979 with Law 9 and its Article 111, the obligation to establish workplace health programs were established, as well as the years 1984 and 1989. Then, in the year 2012 through Law 1562, it is defined that these programs will be understood as "workplace health and safety management system". In 2015 and in 2017, regulatory decrees were issued guarantors for their implementation.

According to the Ministry of Labor, "Occupational Safety and Health" is defined as follows: "It consists and involves the development of a logical process in stages, based on continuous improvement, with the aim of anticipating, recognizing, evaluating and controlling the risks that can affect safety and health at work". [13] And it is established that such systems must be implemented under the leadership of the employer, "The SG-SST must be led and implemented by the employer, with the participation of workers, guaranteeing the application of Health and Safety measures in work, improving the behavior of workers, working conditions and environment, and the effective control of hazards and risks in the workplace" [13]. 
Several aspects are highlighted from the previous paragraph:

1. Workers must be included on the process of implementation

2. Behavior change is proposed. It is evident that many of the workers behaviors are prone to occupational risk.

3. Monitoring and control. An "effective control" of the possible risks of the job is established as necessary.

In turn, Resolution 1111 of 2017 presents the "table of values and qualification" of the minimum SG-SST standards, which defines the level of compliance with it. However, the government makes the measures more flexible, and reorganizes it according to the size of the company, to ease compliance and reduce costs in its implementation through resolution 0312 of 2019. Nevertheless, companies at risk IV and $V$, regardless of the number of employees, must meet the minimum standards typified for companies with more than 50 employees; like MHF CONSTRUARK SAS. Image 1 defines those responsible for the implementation of the SG-SST.

\section{Responsible for the design and implementation of the SG-SST}

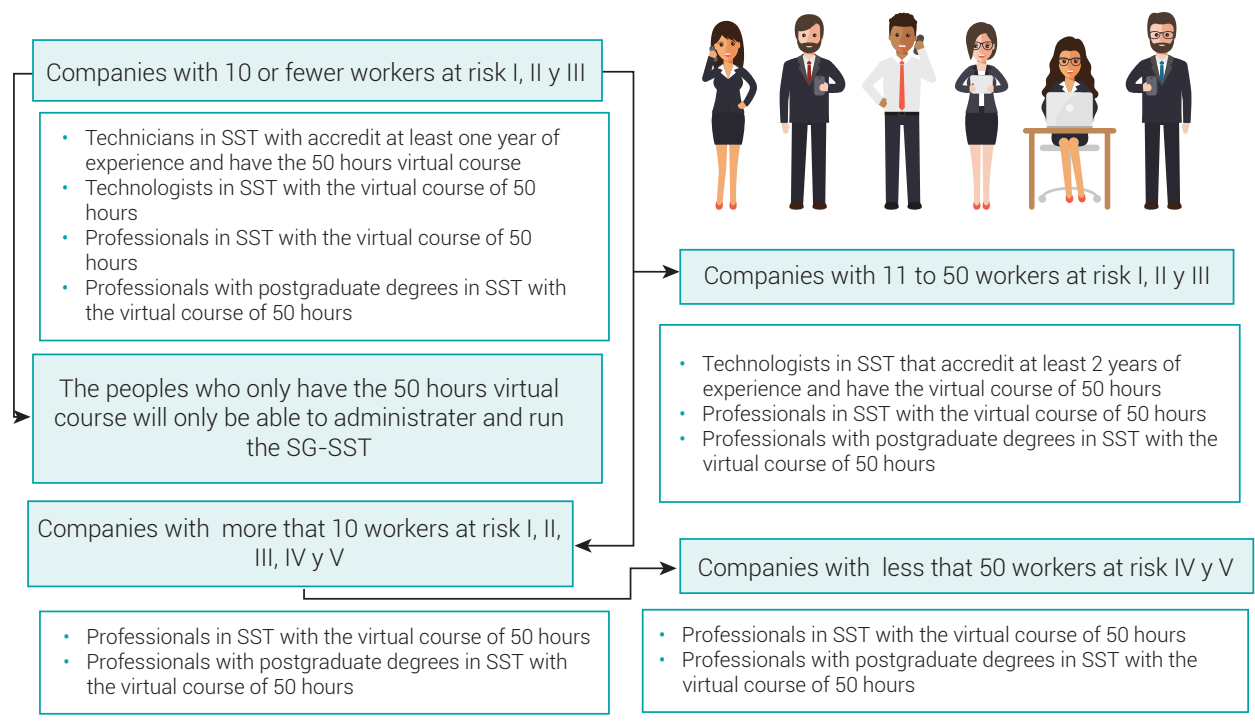

\section{Image 1. Responsible SGSST \\ Source: CCS 2020 [14]}

It is imperative to review some additional norms that are significant in the assembly of the normative references necessary for the consolidation of this System. Decree 472 of 2015 regulates "the criteria for graduation of fines for infringement of the 
Health and Safety Rules at work and workplace risks"; likewise, Resolution 3673, that regulates safe work at heights, an essential activity for the development of the construction field.

The classification of risks within the construction sector was related to the factors that determine, in this sector, the high probability of occurrence of claims, "workers in the construction field are exposed to multiple risk situations, the most frequent being those derived from uncomfortable postures, lifting heavy loads, falling from heights, objects or tools falling, blows, cuts, burns, and so on." [15] The work environment generated in the construction field presents a series of factors that can lead to workplace accidents of various kinds.

The same working conditions that prevail in this sector make the work to implement risk prevention mechanisms an equally problematic factor. In many construction projects, the figure of hiring prevails, which implies transferring to the worker the responsibility of assuming their social security and occupational risks on their own. For Lorento, Salanova \& others "it is in fact very difficult to implement the necessary prevention measures due to their labor structure based on chain subcontracting and the very high turnover " [16]; which are evident in many of the processes in Colombia and are naturally involved in the contracting process for civil construction works.

Nevertheless, the occurrence of workplace accidents has been mitigated due to the implementation of standards and systems to regulate the construction field in the analyses carried out by Fasecolda [17]. Taking the research period to be between 2009 and 2017, and taking into account that Decree 1443 was issued in 2014, it is evidenced that from 2009 to the year 2014, workplace accidents have been consistently increasing, going from $6 \%$ and reaching almost $8 \%$. However, after 2014, a decrease is noted, reaching $6 \%$ in 2017 , considering that the population increased by $50 \%$ in the sector.

\subsection{PURPOSE}

This article gathers the process and results of the research carried out in the company MHF Construark SAS where the implementation of the SGSST was evaluated. Therefore, its scope refers exclusively to the purposes of the investigation, which are basically to contribute to the improvement of such system within the company. With the intention of preventing situations that involve accidents or workplace diseases and, in extreme cases, loss of human life. However, this work allows us to give some key orientations regarding the factors, mainly human, that affect the inadequate implementation of the SGSST. Thus, enclosed within this work, the reader will find the methodological description where the design and the assorted process of this research work are seen, the most significant results and the latest conclusions. 


\section{METHODS AND MATERIALS}

The research carried out was based on the qualitative approach, as its purpose is to "examine and reflect on less tangible aspects of an investigation, such as values, attitudes or perceptions" [18] which implies, from this perspective, establishing the characteristics of the company in relation to the process of implementation of decree 1072 of 2015 from a perspective that aims to identify the role of the human factor in this implementation. Qualitative studies seek "to know the relationship or degree of association that exists between two or more concepts, categories or variables in a particular context" [19]. For this research, the following phases were proposed, see Graph 4.

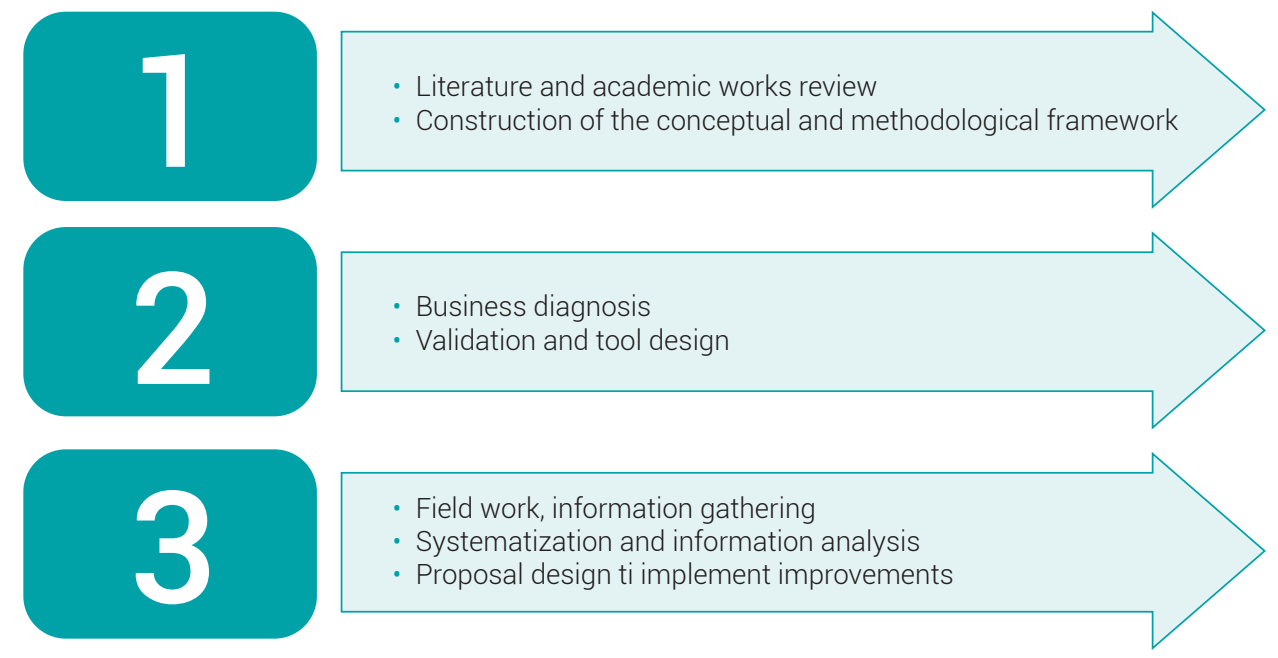

Graph 4. Phases of the implemented method Source: Own work

With these phases it was possible to develop the research and to propose objectives in a relevant way. The methodological proposal for the research took systems theory as a theoretical framework, assuming the company as such. It is necessary to keep in mind the following information, "Systems research incorporates three interrelated domains of disciplined research: systems theory, systems philosophy, and systems methodology" [20]. In terms of the systems methodology and to concatenate with the proposed methodology presented here, the following fragment is referenced in order to understand the way in which the parts are integrated with the system: "When it comes to research about a system, analysis is as important as synthesis. Analysis is so important as it allows us to know the parts of a system, such as synthesis, by means of which we study how the integration of these parts into the system occurs" 
[21]. Systems are defined as "the relationship between the attributes of objects" having to clarify the scope of the concept of "attribute" which in turn is defined as, "it is simply a convenient vehicle to speak or identify an object; or, more properly, the state or condition of the object" [22], that in addition to establishing the relations between parts within the system, the attributes establish the state of those parts or objects.

As part of the implemented method, the steps presented below were used since, in addition to diagnosing, they present concrete alternatives for the development of the proposal made to MHF Construark SAS, since through this action it is possible to "adequately account for of the organization's operation, that is, allowing another observer to witness the described organizational functioning" [23]:

1. Identify the problems to be solved with the collaboration of the members of the system

2. Compilation of historical, current internal and environmental data

3. Consensus and define a preliminary diagnosis by the members

4. Provide feedback on the preliminary diagnosis to members

5. Formalize and describe a joint diagnosis of the problem

6. Jointly define the action to be taken to solve the problem

7. Carry out the implementation of the action agreed by the members

8. Evaluate the results obtained and analyze the new problems that have arisen to start again, looking for solutions and so on, until a complete and satisfactory resolution of the problem to be solved is achieved.

9. All the knowledge and experience obtained are collected and reported for continuous improvement. [21]

The diagnostic process is central to any investigation, as the proper formulation of the problem depends on its rigor. Thus, "process tracing, to reiterate, is an analytical tool to extract descriptive and causal inferences from diagnostic tests, which are often understood as part of a temporal sequence of events or phenomena. Given the close commitment to cases and the centrality of detailed case knowledge, process tracing can make decisive contributions to various investigation objectives" [24].

There has been much work done in relation to the mechanisms necessary for the measurement of quality standards worldwide. An example of this is the FINE method, the INSHT method and the UK's BS 8800. This standard, which dates back to 1996, incorporated key concepts for the subject of Health and Safety at work, such as the health and safety policy, planning and implementation, auditing and periodic review of the state [25]. These methodologies are significant precedents of the mechanisms 
and tools that have been used to measure management systems at work, but specifically with what has to do with health and safety. However, for the research carried out, Resolution 0312 of 2019 was chosen, which incorporates a complete mechanism for measuring quality standards in the field of SG-SST.

Likewise, the GTC 45 standard "guide for the identification of hazards and the assessment of risks in occupational health and safety" was used as a tool for identifying hazards as well as the assessment of risks [37]. In turn, a proposal for improvement in the implementation was designed for the organization that consisted of:

1. Literature review, not only academic but also specific to the organization

2. Design a conceptual framework that would allow linking the SGSST concepts with the realities of the company given its nature as an SME

3. Carry out the diagnosis by appealing to various sources, not only in the administrative area, but also in the operational and technical area, which allowed multiple views of the process

4. The design and validation of the instrument recevied adequate feedback from the people of the company, who reviewed and validated these instruments

5. The proposal made was accepted by the company, expressing the need for its implementation.

\section{RESULTS}

The most relevant results of the research process are presented below:

The level of implementation of Decree 1072 of 2015 in the company was obtained due to the design and application of a checklist to verify the central components of said standard. The results are summarized in Graph 5: 


\begin{tabular}{|l|c|}
\hline \multicolumn{2}{|c|}{ Estado Actual } \\
\hline Health and safety policy & $100 \%$ \\
\hline Employers Obligations & $60 \%$ \\
\hline SGSST training & $50 \%$ \\
\hline Documentation & $60 \%$ \\
\hline Documentation handling & $100 \%$ \\
\hline Comunication, Prevention and preparation & $100 \%$ \\
\hline Initial Evaluation & $100 \%$ \\
\hline Pacification & $100 \%$ \\
\hline Prevention measurements and hiring & $75 \%$ \\
\hline Senior management and audit assessment & $100 \%$ \\
\hline Corrective actions & $100 \%$ \\
\hline Workplace accidents research & $75 \%$ \\
\hline
\end{tabular}

Graph 5. Current state of the SGSST

Source: Own work

It is noticed on the graph that the company has a relatively high level of implementation of the standard. In significant aspects such as the SGSST policy document, $100 \%$ compliance is achieved, as well as prevention, preparation and emergency response. Nevertheless, in topics such as SGSST training, 50\% compliance is present, which is explained, among others, by the situation derived from the pandemic that affected and caused a cessation of activities. The company is taking up the subject through virtual training processes. A SWOT matrix was made, helping "to relate the Weaknesses, Opportunities, Strengths and Threats, leading us to the elaboration of strategies that mitigate the impact of threats and reduce weaknesses, making use of our strengths and taking advantage of opportunities" [26] Table 3.

\section{Table 3. SWOT matrix}

\begin{tabular}{|c|c|c|}
\hline & STRENGTHS & WEAKNESSES \\
\hline INTERNAL & $\begin{array}{l}\text { - SST policy. The policy achieves } 100 \% \text { of } \\
\text { implementation. } \\
\text { - Emergency attentions prevention. } \\
\text { - Document handling. } \\
\text { - Communications. } \\
\text { - Initial assessment. } \\
\text { - Planification. } \\
\text { - Prevention and control measurements, occasional. } \\
\text { - Hiring } \\
\text { - Workplace accidents research } \\
\text { - Corrective and prevention actions }\end{array}$ & $\begin{array}{l}\text { - Employer's obligations. } \\
\text { - Documentation. } \\
\text { - SGSST training. } \\
\text { - Indicators Matrix. } \\
\text { - Senior management and audit } \\
\text { assessment. }\end{array}$ \\
\hline
\end{tabular}




\begin{tabular}{|c|c|c|}
\hline & - OPPORTUNITIES & - THREATS \\
\hline \multirow{6}{*}{ EXTERNAL } & \multirow{6}{*}{$\begin{array}{l}\text { - SST management system strengthening. } \\
\text { - Government and ARL } \\
\text { accompaniment in order to get back to normal } \\
\text { operation. } \\
\text { - Biosafety protocols creation. } \\
\text { - Business reorganization according to the govern- } \\
\text { ment measurements (work from home, part time } \\
\text { work from home so forth) protocol setting and } \\
\text { update for business advantage. }\end{array}$} & \multirow{2}{*}{$\begin{array}{l}\text { Declaration of pandemic due to } \\
\text { COVID-19 has affected society in } \\
\text { general and all business fields, } \\
\text { particularly the construction field } \\
\text { has been affected }\end{array}$} \\
\hline & & \\
\hline & & \multirow{2}{*}{$\begin{array}{l}\text { Price variability in order to guaran- } \\
\text { tee supplies and all the needs and } \\
\text { operative processes of the company }\end{array}$} \\
\hline & & \\
\hline & & $\begin{array}{l}\text { - Possible infection of COVID-19 due } \\
\text { to many uncontrollable factors. }\end{array}$ \\
\hline & & $\begin{array}{l}\text { - Loss of customers due to some } \\
\text { companies being bankrupt. }\end{array}$ \\
\hline
\end{tabular}

Source. Own work

Finally, the VESTER matrix, Table 4 and Graph 6, was worked on, which has been defined as a tool that helps "to identify the causes and effects of a problematic situation" [27] for which the disadvantages identified were taken as a problematic situation for the proper implementation of the SGSST. The variables to incorporate were the weaknesses identified in the SWOT:

Table 4. VESTER matrix

\begin{tabular}{|c|c|c|c|c|c|c|c|c|c|c|c|c|c|c|c|}
\hline \multicolumn{11}{|c|}{$\begin{array}{l}\text { Plantilla Matriz de Vester } \\
\text { Matrix Vester template }\end{array}$} & \multicolumn{5}{|c|}{ CDIGTRUFRK GAE } \\
\hline \multicolumn{16}{|c|}{ Problematic situacion } \\
\hline \multicolumn{16}{|c|}{$\begin{array}{l}\text { Weaknessess on the implementation of workplace health and safety system in MHF } \\
\text { company MHF Construark SAS }\end{array}$} \\
\hline Códe & Variable & P1 & P2 & P3 & P4 & P5 & P6 & P7 & P8 & P9 & P10 & P11 & P12 & P13 & INFLUENCE \\
\hline $\mathrm{P} 1$ & $\begin{array}{l}\text { Lack of role assig- } \\
\text { nment }\end{array}$ & 0 & 0 & 1 & 0 & 0 & 0 & 2 & 1 & 1 & 0 & 0 & 1 & 1 & 7 \\
\hline P2 & Lack of accountability & 2 & 0 & 0 & 0 & 0 & 1 & 3 & 2 & 1 & 0 & 0 & 1 & 1 & 11 \\
\hline P3 & $\begin{array}{l}\text { Lack of management } \\
\text { systems }\end{array}$ & 0 & 0 & 0 & 0 & 0 & 1 & 1 & 2 & 0 & 0 & 1 & 1 & 1 & 7 \\
\hline P4 & $\begin{array}{l}\text { There are no epide- } \\
\text { miological surveillance } \\
\text { programs }\end{array}$ & 1 & 0 & 2 & 0 & 1 & 1 & 1 & 2 & 0 & 0 & 1 & 1 & 1 & 11 \\
\hline P5 & $\begin{array}{l}\text { No environmental } \\
\text { assessments are } \\
\text { performed }\end{array}$ & 2 & 1 & 2 & 1 & 0 & 1 & 1 & 1 & 1 & 1 & 1 & 1 & 1 & 14 \\
\hline P6 & $\begin{array}{l}\text { There are no structu- } \\
\text { ral, result and process } \\
\text { indicators }\end{array}$ & 0 & 1 & 1 & 0 & 0 & 0 & 1 & 2 & 0 & 0 & 3 & 1 & 1 & 10 \\
\hline P7 & $\begin{array}{l}\text { There has not been } \\
\text { any responsabilities } \\
\text { regarding accountabi- } \\
\text { lity established }\end{array}$ & 2 & 3 & 1 & 1 & 0 & 1 & 0 & 2 & 1 & 1 & 0 & 1 & 2 & 15 \\
\hline
\end{tabular}

(continúa) 
(viene)

\begin{tabular}{|c|c|c|c|c|c|c|c|c|c|c|c|c|c|c|c|}
\hline \multicolumn{11}{|c|}{$\begin{array}{l}\text { Plantilla Matriz de Vester } \\
\text { Matrix Vester template }\end{array}$} & \multicolumn{5}{|c|}{ CDIGTRUFRK EFG } \\
\hline \multicolumn{16}{|c|}{ Problematic situacion } \\
\hline \multicolumn{16}{|c|}{$\begin{array}{l}\text { Weaknessess on the implementation of workplace health and safety system in MHF } \\
\text { company MHF Construark SAS }\end{array}$} \\
\hline Códe & Variable & P1 & P2 & P3 & P4 & P5 & P6 & P7 & P8 & P9 & P10 & P11 & P12 & P13 & INFLUENCE \\
\hline P8 & $\begin{array}{l}\text { There has not been } \\
\text { any internal audits } \\
\text { performed }\end{array}$ & 0 & 1 & 2 & 0 & 0 & 2 & 2 & 0 & 2 & 1 & 0 & 1 & 2 & 13 \\
\hline P9 & $\begin{array}{l}\text { The SGSST scheduled } \\
\text { work plan has not } \\
\text { been finished }\end{array}$ & 0 & 1 & 1 & 0 & 0 & 0 & 1 & 1 & 0 & 1 & 0 & 1 & 1 & 7 \\
\hline P10 & $\begin{array}{l}\text { The SGSST training } \\
\text { has not been } \\
\text { completed }\end{array}$ & 0 & 0 & 1 & 0 & 0 & 1 & 1 & 1 & 2 & 0 & 0 & 1 & 1 & 8 \\
\hline P11 & $\begin{array}{l}\text { The activities safety } \\
\text { standards have not } \\
\text { been finished }\end{array}$ & 1 & 1 & 3 & 2 & 2 & 2 & 2 & 2 & 2 & 2 & 0 & 1 & 1 & 21 \\
\hline $\mathrm{P} 12$ & $\begin{array}{l}\text { There has not been a } \\
\text { review of the schedu- } \\
\text { led work plan }\end{array}$ & 1 & 1 & 1 & 0 & 0 & 1 & 3 & 2 & 3 & 1 & 0 & 0 & 1 & 14 \\
\hline $\mathrm{P} 13$ & $\begin{array}{l}\text { The senior manage- } \\
\text { ment review has not } \\
\text { been documented }\end{array}$ & 0 & 2 & 1 & 0 & 0 & 2 & & 2 & 2 & 0 & 0 & 1 & 0 & 10 \\
\hline \multicolumn{2}{|r|}{ DEPENDENCE } & 9 & 11 & 16 & 4 & 3 & 13 & 18 & 20 & 15 & 7 & 6 & 12 & 14 & 74 \\
\hline
\end{tabular}

Source. Own work

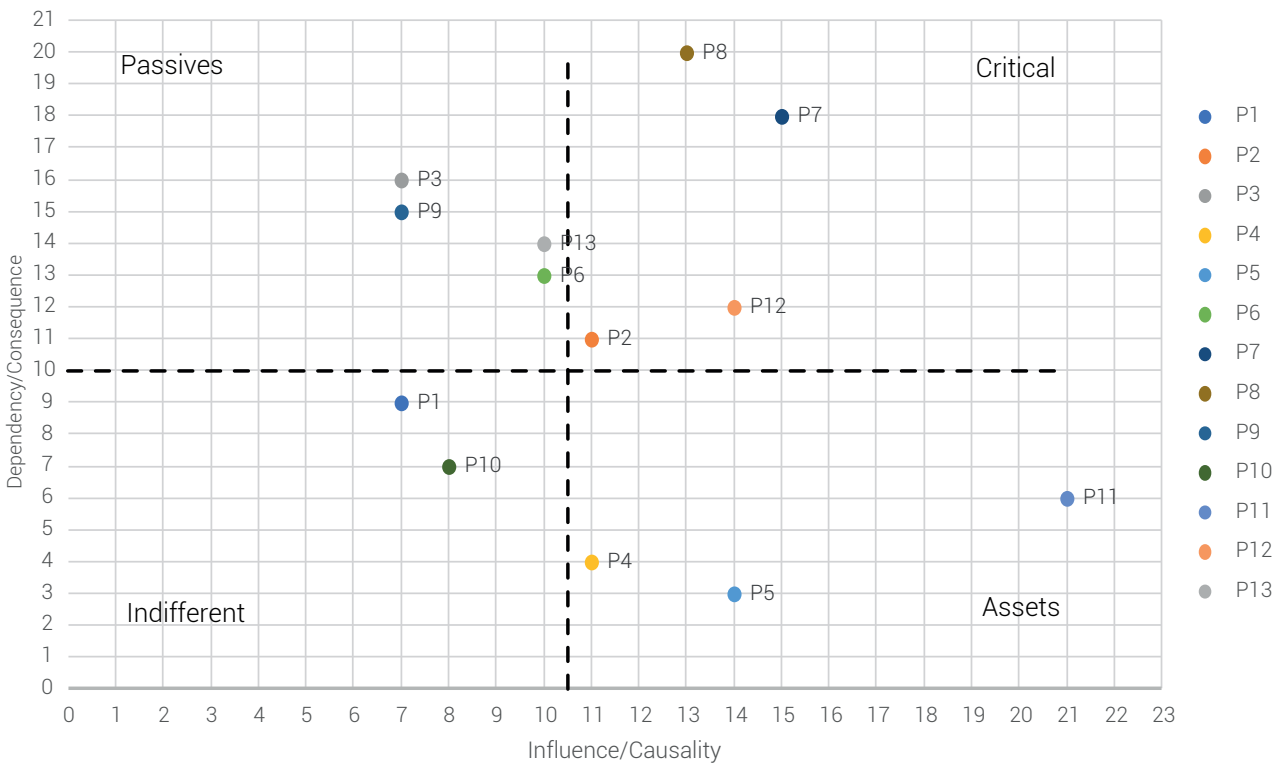

Graph 6. Classification

Source: Own work 
The VESTER matrix and its results basically ratify the problems identified in the SWOT, referring to the weaknesses in the implementation of the SGSST. It is pertinent to highlight that, for instance, in relation to problem P8 (audits) it is clear that the absence of these may determine the non-identification of central aspects in the implementation of the SGSST, making it difficult to implement it properly. Therefore, it will be advisable for the company to hire an audit that identifies problematic situations in the SGSST which, as established, are in the planning process for its hiring.

Considering the regulations in force in the country, in terms of occupational health, the results were obtained after conducting surveys, semi-structured interviews and the survey of hazard and risk factor landscapes. In accordance with the current Colombian standard GTC-45 [37], the matrix is carried out on the basis of this methodology managing to establish the following:

1. Use of toiletries for general cleaning (cleaners, disinfectants, flavorings)

2. Prolonged posture held in information processing activities involving sedentary positions

3. Repetitive movements in data entry and mouse manipulation

Some examples of these are presented:

1. Handling of low voltage electrical equipment (cutting machine, polisher, tile cutter, laser saw, drills, hammer drill, welding equipment, spinning top). Laying and using extension cords.

2. Handling of used sanitary units

3. Particulate material and inorganic powders from the handling of cements, sands and concretes. Mixing of mortar and concrete. Particulate material generated and excavation. Dusts and particulate matter from sanding, polishing, roughing, , digging

At the same time, it has been highlighted that, within the intervention measures, a central emphasis was placed on the measures of "administrative controls". However, within the classification of the danger linked to COVID-19, in addition to the administrative controls, some engineering controls that seek to modify the spaces are already incorporated, in order to mitigate the possible spread of the virus.

The level of implementation has been proven through documentation. Since one of the factors identified as missing was the matrix of process, structure and result 
indicators, from the development of the research a proposal of an indicator matrix was made, the function of the indicators in companies is that it allows them to "detect, quickly and precisely, which are the specific aspects in which they can and should improve. SG-SST indicators are those tools that allow a company to evaluate the results of its management, identify opportunities to improve and adapt the goals to a more realistic vision" [28]. This was delivered to the company as part of the recommendations, see Table 5.

Table 5. Matrix Indicators

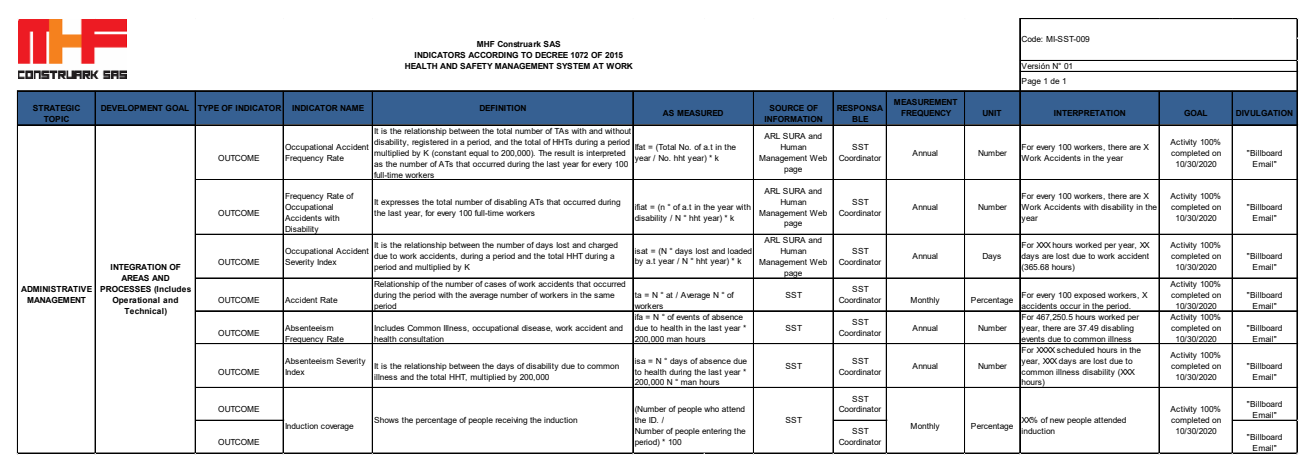

Source: Own work

The type of indicator, the name, the way it is measured, the source of information, the person responsible, the frequency of measurement, the unit and its interpretation, as well as the goal and the means of distribution were defined.

For the general validation of the SGSST, the matrix proposed by Erazo and Rodríguez [29] was used, where precise elements are provided to establish an assessment of the level of implementation. There are many benefits that arise from the development of this type of tool, since they not only serve "as a reference to assess a level of progress in terms of integration, but also allow the identification of specific aspects that need to be improved" [30]. In this way, it is possible to assess the level of implementation in the MHF company at 85.47 points.

To reach this percentage, the company had been carrying out procedures and development of processes and activities in order to complement the work carried out, to achieve the implementation commitments of the health and safety management system at work. Thanks to this, in a short time, a high standard of compliance is achieved. The applied matrix was the following, see Table 6. 
Table 6. Validation SGSST

\begin{tabular}{|c|c|c|c|}
\hline EFE & \multicolumn{3}{|c|}{$\begin{array}{c}\text { Validation Table SGSST } \\
\text { MHF Company }\end{array}$} \\
\hline Dimensions & Criteria & Evaluation & Score \\
\hline \multirow{6}{*}{$\begin{array}{l}\text { Context of the } \\
\text { organization }\end{array}$} & Understanding the context of the organization & 3 & 1.80 \\
\hline & $\begin{array}{l}\text { Understand the needs and expectations of workers } \\
\text { and other stakeholders }\end{array}$ & 3 & 1.80 \\
\hline & Leadership, worker participation and consultation & 3 & 1.80 \\
\hline & Policy & 4 & 2.40 \\
\hline & $\begin{array}{l}\text { Organization of roles, responsibilities and autho- } \\
\text { rities }\end{array}$ & 4 & 2.40 \\
\hline & Participation, consultation and representation & 3 & 1.80 \\
\hline \multirow{3}{*}{ Planning } & Planning Actions to face risks and opportunities & 4 & 2.40 \\
\hline & Risks and Hazards Identification and evaluation & 4 & 2.40 \\
\hline & Hazard identification & 4 & 2.40 \\
\hline \multirow{5}{*}{ Support } & Resources & 4 & 2.00 \\
\hline & Competition & 4 & 2.00 \\
\hline & Consciousness & 4 & 2.00 \\
\hline & Information and communication & 4 & 2.00 \\
\hline & Information documentation & 4 & 2.00 \\
\hline \multirow{6}{*}{ Operation } & Operation Planning and operational controls & 3 & 3.60 \\
\hline & Hierarchy of controls & 4 & 4.80 \\
\hline & Change management & 4 & 4.80 \\
\hline & Subcontracting & 4 & 4.80 \\
\hline & Hiring & 4 & 4.80 \\
\hline & Emergency Plan Devise & 4 & 4.80 \\
\hline \multirow{6}{*}{ Performance Evaluation } & $\begin{array}{l}\text { Performance evaluation Monitoring, measurement, } \\
\text { analysis and evaluation }\end{array}$ & 3 & 3.60 \\
\hline & Method & 4 & 4.80 \\
\hline & Performance evaluation & 3 & 3.60 \\
\hline & Compliance evaluation & 4 & 4.80 \\
\hline & External audit & 3 & 3.60 \\
\hline & Internal audit & 3 & 3.60 \\
\hline \multirow[t]{2}{*}{ Improvement } & $\begin{array}{l}\text { Improvement Incidents, nonconformity and correc- } \\
\text { tive action }\end{array}$ & 3 & 1.20 \\
\hline & Continuous improvement & 3 & 1.20 \\
\hline Total & & & 83.2 \\
\hline
\end{tabular}

Source: Own work 
Therefore, as it has been stated in the development of the text, the level of implementation is at a high level. Finally, the proposal for the improvement of the SGSST is presented within MHF Construark SAS, see Table 7.

Table 7. Improvement proposal for MHF Construark SAS

\begin{tabular}{|c|c|c|c|}
\hline Dimensions & Criteria & Actions to Take & Accountable \\
\hline \multirow{6}{*}{$\begin{array}{l}\text { Context of the } \\
\text { Organization }\end{array}$} & \multirow{2}{*}{$\begin{array}{l}\text { Understanding the con- } \\
\text { text of organization }\end{array}$} & \multirow{2}{*}{$\begin{array}{l}\text { It is proposed to strengthen the } \\
\text { internal training processes from the } \\
\text { administrative area to guarantee } \\
\text { an adequate understanding of the } \\
\text { context of the organization }\end{array}$} & Management Area \\
\hline & & & $\begin{array}{l}\text { Human Resources } \\
\text { Department }\end{array}$ \\
\hline & \multirow{2}{*}{$\begin{array}{l}\text { Understand the needs } \\
\text { and expectations of } \\
\text { workers and other stake- } \\
\text { holders }\end{array}$} & \multirow{2}{*}{$\begin{array}{l}\text { Conduct surveys and diagnoses to } \\
\text { identify the needs and expectations of } \\
\text { workers and other interested parties }\end{array}$} & Management Area \\
\hline & & & $\begin{array}{l}\text { Human Resources } \\
\text { Department }\end{array}$ \\
\hline & \multirow{2}{*}{$\begin{array}{l}\text { Leadership, worker parti- } \\
\text { cipation and consultation }\end{array}$} & \multirow{2}{*}{$\begin{array}{l}\text { Promote behaviors prone to parti- } \\
\text { cipation through training programs, } \\
\text { informative capsules, among others. }\end{array}$} & Management Area \\
\hline & & & $\begin{array}{l}\text { Human Resources } \\
\text { Department }\end{array}$ \\
\hline \multirow{4}{*}{ Support } & \multirow{3}{*}{ Awareness } & \multirow{3}{*}{$\begin{array}{l}\text { Promoting awareness is crucial so } \\
\text { that the appropriation of the SGSST is } \\
\text { relevant. Training processes and ac- } \\
\text { companying, monitoring and control } \\
\text { measures are suggested. }\end{array}$} & Management Area \\
\hline & & & $\begin{array}{l}\text { Human Resources } \\
\text { Department }\end{array}$ \\
\hline & & & SISOMA ${ }^{1}$ professionals \\
\hline & $\begin{array}{l}\text { Information documen- } \\
\text { tation }\end{array}$ & $\begin{array}{l}\text { The duration of the documents must } \\
\text { be guaranteed. For this, it is necessary } \\
\text { to promote their preservation through } \\
\text { the inclusion of these in the special } \\
\text { protective acetates }\end{array}$ & $\begin{array}{l}\text { Administrative Area } \\
\text { Archive }\end{array}$ \\
\hline Operation & $\begin{array}{l}\text { Planning and operational } \\
\text { controls }\end{array}$ & $\begin{array}{l}\text { Strengthen planning processes in the } \\
\text { operational area. Through practical } \\
\text { workshops that manage to fine-tune } \\
\text { the planning process and its selected } \\
\text { controls }\end{array}$ & Operational area \\
\hline \multirow{7}{*}{$\begin{array}{l}\text { Performance } \\
\text { evaluation }\end{array}$} & $\begin{array}{l}\text { Monitoring, measu- } \\
\text { rement, analysis and } \\
\text { evaluation }\end{array}$ & $\begin{array}{l}\text { Implementation of the matrix of } \\
\text { indicators }\end{array}$ & Administrative Area \\
\hline & \multirow{3}{*}{ Methods } & \multirow{3}{*}{$\begin{array}{l}\text { The performance evaluation must be } \\
\text { updated, and the company have to } \\
\text { adjust the method and it should be } \\
\text { SGSST oriented }\end{array}$} & Management Area \\
\hline & & & $\begin{array}{l}\text { Human Resources } \\
\text { Department }\end{array}$ \\
\hline & & & SISOMA professionals \\
\hline & \multirow[t]{2}{*}{ Performance evaluation } & \multirow{2}{*}{$\begin{array}{l}\text { The company must also program } \\
\text { performance evaluation processes, } \\
\text { adjusted to compliance with the } \\
\text { SGSST in order to make the required } \\
\text { improvements when a non-conformity } \\
\text { is identified. }\end{array}$} & $\begin{array}{l}\text { Human Resources } \\
\text { Department }\end{array}$ \\
\hline & & & SISOMA professionals \\
\hline & External audit & An external audit must be hired & $\begin{array}{l}\text { Consulting company } \\
\text { in systems audits with } \\
\text { an emphasis on SGSST }\end{array}$ \\
\hline
\end{tabular}

(continúa)

\section{SISOMA: Expert professional in Industrial Safety, Occupational Health, Environment}



(viene)

\begin{tabular}{|c|c|c|c|}
\hline Dimensions & Criteria & Actions to Take & Accountable \\
\hline \multirow[b]{3}{*}{$\begin{array}{l}\text { Performance } \\
\text { evaluation }\end{array}$} & \multirow[t]{2}{*}{ Internal Audit } & \multirow{2}{*}{$\begin{array}{l}\text { Once external audit is hired, Internal } \\
\text { audit must be set up to make sure it is } \\
\text { complemented }\end{array}$} & $\begin{array}{l}\text { Human Resources } \\
\text { Department }\end{array}$ \\
\hline & & & SISOMA professionals \\
\hline & Management Review & $\begin{array}{l}\text { Senior management undertakes to } \\
\text { carry out permanent review and mo- } \\
\text { nitoring processes for the implemen- } \\
\text { tation of the SGSST. They must carry } \\
\text { out specific committees to monitor } \\
\text { the implementation of the SGSST }\end{array}$ & Senior Management \\
\hline \multirow[t]{3}{*}{ Improvement } & $\begin{array}{l}\text { Incidents, non-conformity } \\
\text { and corrective action }\end{array}$ & $\begin{array}{l}\text { The company must carry out greater } \\
\text { controls to enable the reduction } \\
\text { of incidents, nonconformities and } \\
\text { corrections. It should be clarified that } \\
\text { the incidents are minimal, as well as } \\
\text { the disagreements on the part of the } \\
\text { clients. }\end{array}$ & $\begin{array}{l}\text { Technical Area, } \\
\text { Operational Area and } \\
\text { Administrative Area as } \\
\text { support }\end{array}$ \\
\hline & \multirow[b]{2}{*}{ Continuous Improvement } & \multirow{2}{*}{$\begin{array}{l}\text { Main purpose for the company, but } \\
\text { it becomes relevant in terms of the } \\
\text { implementation and improvement of } \\
\text { the SGSST. }\end{array}$} & Management \\
\hline & & & $\begin{array}{l}\text { SISOMA professionals } \\
\text { and all employees in } \\
\text { general }\end{array}$ \\
\hline
\end{tabular}

Source. Own work

This improvement proposal specifies the aspects identified as "non-conformities" in relation to what is established in Decree 1072 and in the Occupational Health and Safety policy, and with the application of this proposal it is sought to raise the level to 95\% compliance. It is imperative to specify the importance of activities such as audits. For instance, internal auditing has significant preponderance since it is understood as "an independent and objective evaluation activity to add value and improve the accounting, financial and administrative operations of an organization, helping it to achieve its objectives, through evaluation, improvement and process efficiency, thus providing an effective service to the highest levels of the administration" [31]. On the other hand, the external audit "is carried out by personnel external to the company where it examines and evaluates its operations, in order to issue a truthful and technical opinion of the control system that is being developed in that area" [32].

\section{DISCUSSION AND CONCLUSSIONS}

Among the most relevant findings regarding the execution of the main causes that affect the implementation of the SGSST is the human factor role in these situations. Although it is true, the Colombian regulations and the purposes of the Ministry of Labor [13]. To carry out an adequate implementation, this work shows that there is 
still a long way to go, as one of the deficiencies appears in senior management (operational and technical area management) and a poor willingness to develop actions to improve the implementation, such as audits, or the mandatory nature of determining aspects for the operation on site.

In fact, a lack of leadership is revealed on behalf of the senior management due to the fact they show poor commitment on the act of implementing the system and resistance to change, while some factors still prevail that downplay the latency of risks related to construction work. "The leadership, commitment and involvement of top management are essential for the implementation, development and maintenance of an effective and efficient management system to achieve the benefits of the organization and all stakeholders" [33]. It is a must for the success of these systems; however, it is still considered that the SGSST, before being an element of prevention, is an impending factor of the operation on site

If the suspension of key activities, such as training, is added to those described above, among others, to external conjectural factors (COVID Pandemic), it is possible to understand why the company has not yet reached $100 \%$ in the implementation. The training contributes centrally to the appropriation of the standard and the SGSST to guarantee that its compliance is part of the daily life of the company. This is so since "training is one of the personnel procedures used by the company to achieve its organizational purposes" [34].

Nevertheless, the foregoing, some observations given by the personnel in charge of doing these trainings allow us to infer that the level of appropriation of this knowledge is minimal, as its applicability in practice becomes difficult and they cite, for instance, the inadequate use of masks. Despite training and billboards, the disciplinary actions fail to modify the behavior of employees.

Even though, it was possible to demonstrate an adequate process of application of preventive and corrective actions in the various situations that were detected in non-conformities on the part of human resources, such situations also show that in practice, situations contrary to what is established by the SGSST in matters of safety and accident prevention still occur. That is, the way in which the human resource defined as labor has not yet appropriately embraced the use of, for instance, PPE, which puts their integrity at risk and also triggers the application of corrective measures.

Finally, it is required to reiterate the importance of the SGSST in relation to the other management systems, taking into account that there are synchronicities necessary to guarantee for adequate business management and risk management. As stated by Carvajal and Molano "management systems in health and safety are used in the tool that facilitates dialogue, under the same language between the management 
in health and safety at work with the organizational management, for the prevention of workplace hazards but it is not in itself the objective pursued, since it is likely that, based on the principle of continuous improvement, the process of risk prevention will be improved, but its effectiveness will depend essentially on all the factors involved in the management of health and safety at work "[35]. These concerns do not only occur in the national context. In fact, in the United States, the concern has been such that there are even investigations that try to establish the orientation and the true contribution of academic research on these issues [36]. Construction occupational health and safety research published in high-impact peer-reviewed academic journals between 2002 and 2016 was "reviewed to assess whether research in the field is efficiently directed to produce evidence-based interventions that address risks associated with the most serious occupational problems in the industry". [36]

\section{REFERENCIAS}

[1] M. Cespedes y J. Martinez, «Un Análisis De La Seguridad Y Salud En El Trabajo En El Sistema Empresarial Cubano,» Revista Latinoamericana de Derecho Social, vol. 22, pp. 1-46, 2016, doi: http: //dx.doi.org/10.1016/j.rlds.2016.03.001.

[2] J. Kohen, «Nuevas relaciones laborales y salud de los trabajadores en Argentina. Desafíos y perspectivas para la investigación,» Cuardenos de saúde pública, vol. 13, 1997, doi: http: // dx.doi.org/10.1590/S0102-311X1997000600005

[3] P. Antão, T. Almeida, C. Jacinto y C. Guedes Soares, «Causes of occupational accidents in the fishing sector in Portugal, » Safety Science, vol. 46, no. 6, pp. 935-948, 2008, doi: https://doi. org/10.1016/j.ssci.2007.11.007

[4] M. Santa María, «Desempeño reciente del sectorconstruccióny perspectivas 2020,» La República, 15 abril 2020. [En línea]. Available: https://www.larepublica.co/analisis/anif-2941063/ desempeno-del-sector-construccion-y-perspectivas-2020-2991939

[5] J. Montes y A. Saavedra, «Estudio de la correlación entre variables laborales, en la mano de obra usada en proyectos de construcciones urbanos,» Universidad Católica de Colombia, Bogotá, pp. 17,18. 2018.

[6] J. A. R. L. J. R. \&. H. P. H. Ortega Alarcón, «Importancia de la seguridad de los trabajadores en el cumplimiento de procesos, procedimientos y funciones,» Academia \& Derecho, vol. 8, no. 14, pp. 155-176, 2017, doi: https://doi.org/10.18041/2215-8944/academia.14.1490 
[7] Hoy Construcción.com, «Trabajo informal reina en el sector construcción,» Hoyconstrucción. com, 30 mayo 2018. [En línea]. Available: https://hoyconstruccion.com/actualidad/96/trabajo-informal-reina-en-el-sector-construccion. [último acceso: 27 septiembre 2020], P. 1

[8] A. Chacon, «Diseño y documentación del sistema de gestión en seguridad y salud en el trabajo, para empresa contratista en obras civiles,» Fundación Universitaria los Libertadores, Bogotá, pp. 11. 2016.

[9] L. Bertalanffy, Teoría General de los Sistemas, México: Fondo de Cultura Económica, pp 56 2014.

[10] G. Diaz, «Teoría General de la calidad y de sistemas como elementos fundamentales para la introducción del enfoque basado en procesos a la gestión de Calidad Iso 9001:2000 en las organizaciones,» Instituto Tecnológico de la Construcción, México, pp 46. 2003.

[11] A. Gutiérrez, «Aplicación de los Círculos de Calidad en una organización,» Universidad Autónoma del Estado de Hidalgo, Pachuca, pp 6,9,10. 2005.

[12] Ministerio del Trabajo, «Antecedentes Normativos,» Ministerio del Trabajo, 20 febrero 2015. [En línea]. Available: https://www.mintrabajo.gov.co/relaciones-laborales/riesgos-laborales/ sistema-de-gestion-de-seguridad-y-salud-en-el-trabajo/antecedentes-normativos.

[13] Ministerio del Trabajo, «Sistema de Gestión de la Seguridad y salud en el trabajo. Guía Técnica de implementación para Mipymes, » MIN Trabajo, Bogotá, 2014. Pp10.

[14] Consejo colombiano de Seguridad, «Nuevos Estándares Mínimos derogan la Resolución 1111,» CCS, 21 febrero 2020. [En línea]. Available: https://ccs.org.co/nuevos-estandares-minimos-derogan-la-resolucion-1111/?doing_wp_cron=1601151338.03957295417785644 53125.

[15] J. Martínez, «Riesgos laborales en la construcción. Un análisis sociocultural,» Universitas. Revista de ciencias sociales y humanas, no. 23, pp. 65-86, 2015, doi: https://doi.org/10.17163/ uni.n23.2015.03.

[16] L. Lorento, M. Salanova y I. Martínez, «La relación entre el exceso de Confianza y los accidentes laborales en trabajadores de la Construcción: un Estudio Cualitativo. » Revista Riesgos laborales.com, no. 84, pp. 8-13, octubre 2011, doi: http://dx.doi.org/10.22201/ fesi.23958979e.2019.8.15.69157

[17] SAFETYA, «safetya.co,» 29 noviembre 2018. [En línea]. Available: https://safetya.co/ accidentes-de-trabajo-en-colombia-en-cifras-2018/. 

prevention of workplace accidents with MHF Construark SAS, carried out during the year 2020 in Bogotá

[18] C. Neville, «Introduction to Research and Research Methods, » July 2007. [En línea]. Available: https://www.unrwa.org/sites/default/files/introduction-to-research-and-research-methods.pdf.

[19] H. Sampieri, F. Collado y B. Lucio, Metodología de Investigación, México: Mc Graw Hill, 2006, p. 81.

[20] J. Del Valle, «El Enfoque de Sistemas: Una Herramienta de la Planeación,» [En línea]. Available: https://www.ingenieria.unam.mx/javical/planeacion/Planeacion/MarcoSistemas.htm.

[21] Actualidad Empresa, «Metodología Sistémica Para Un Proceso Estratégico Empresarial,» actualidad empresa. Com, 2211 2017. [En línea]. Available: http://actualidadempresa.com/ metodologia-sistemica-proceso-estrategico-empresarial/.

[22] T. Y. Mesarovic M.D., «Abstract Systems Theory. Lecture Notes in Control and Information Sciences,» Springer, Berlin, Heidelberg, vol. 116, pp. 1-11, 2006.

[23] D. Rodríguez, Diagnostico Organizacional, Santiago de Chile: Ediciones UC, 2015, p. 29.

[24] D. Colier, «Understanding Process Tracing,» PS: Political Science \& Politics, vol. 44, no. 4, pp. 823-830, 2011.

[25]SENA- Ministerio del Trabajo, «Formación en ambientes virtuales de aprendizaje. Planificación del sistema de gestión de la seguridad y salud en el trabajo,» SENA - Min Trabajo, Bogotá, 2020, P. 1

[26] D. Barrera, «La importancia de la matriz DOFA como herramienta de diagnóstico,» Emprendices, 25 Septiembre 2013. [En línea]. Available: https://www.emprendices.co/ la-importancia-de-la-matriz-dofa-como-herramienta-dediagnostico/\#: :text=La\%20matriz\%20DOFA\%2C\%20como\%20bien,nuestras\%20fortalezas\%20y\%20aprovechando\%20 oportunidades..

[27] D. F. Betancourt, «Matriz de vester para la priorización de problemas», Ingenio Empresa, 19 junio 2016. [En línea]. Available: www.ingenioempresa.com/matriz-de-vester

[28] Safetya, «Los indicadores del SG-SST, una garantía técnica», Safetya, 19 Agosto 2015. [En línea]. Available: https://safetya.co/los-indicadores-una-garantia-tecnicadelsgsst/\#: :text=Los\%20 indicadores\%20del\%20SG\%2DSST\%20son\%20esas\%20herramientas\%20que\%20le,a\%20 una\%20visi\%C3\%B3n\%20m\%C3\%A1s\%20realista.. 
[29] G. Erazo y L. Rodríguez, «Diseño y validación de contenido de un instrumento para medir la gestión y la seguridad y salud en el trabajo para organizaciones colombianas,» Signos, vol. 8, no 2. pp. 65-80, 2016

[30] H. Hernández y A. Parra, «Instrumento para medir el nivel de integración de los sistemas de gestión en organizaciones colombianas», Universidad Santo Tomas- Icontec, Bogotá, pp13. 2018.

[31] C. Moncayo, «Importancia de la auditoría interna en las organizaciones», Instituto Nacional de Contadores Públicos Colombia, 9 abril 2015. [En línea]. Available: https://www.incp.org. co/importancia-de-la-auditoria-interna-en-las-organizaciones/.

[32] L. Grimaldo, «La importancia de las auditorías internas y externas dentro de las organizaciones», Universidad Militar Nueva Granada, Bogotá, pp13. 2014.

[33] EOI, «La Alta Dirección: parte fundamental en los Sistemas de Gestión,» EOl.es Blog, [En línea]. Available: https://www.eoi.es/blogs/olatzripoll/2012/05/31/la-alta-direccion -parte-fundamental-en-los-sistemas-de-gestion/.

[34] M. Ruiz y A. Díaz, «Capacitar: clave para reducir riesgos de trabajo», 1996. [En línea]. Available: https://www.uv.mx/iiesca/files/2013/01/capacitar1996.pdf.

[35] D. Carvajal y J. Molano, «Aporte de los sistemas de gestión en prevención de riesgos laborales a la gestión de la salud y seguridad en el trabajo,» Movimiento Científico, vol. 6, no. 1, pp. 158174, 2012.

[36] C. Sinyai y S. Cohi, «Fifteen years of American construction occupational safety and health research», Safety Science, vol. 131, 2020.

[37] F. A. Bolaños-Alomia, "Condiciones institucionales de higiene, salud, seguridad y medio ambiente, en la población estudiantil de instituciones educativas técnicas en Pasto," Ingeniería Solidaria, vol. 10, no. 17, pp. 93-103, en.-dic., 2014, doi: http://dx.doi.org/10.16925/ in.v9i17.809.

[38] J. García, A. Marcano y N. Cantillo, "Estrategia y habilidades para la competitividad: caso de pymes del sector construcción en Barranquilla”. Aglala, vol. 10, no. 1, pp. 312-339. [En línea]. Available: http://revistas.curnvirtual.edu.co/index.php/aglala/article/view/1349

[39] L. Durán, "Estrategia de gestión basada en el cuadro de mando integral para la empresa Herrametal C.A. ubicada en municipio Iribarren, Estado Lara”. Enfoque Disciplinario, vol. 3, no. 1, pp. 49-71, 2018. [En línea]. http://enfoquedisciplinario.org/revista/index.php/enfoque/ article/view/12 